tumor of distal end radius". Arch Orthop Trauma Surg, 130, 1467-1473.

4. Chung DW, Han CS, Lee JH, Lee SG (2012) "Outcomes of wrist arthroplasty using a fre vascularized fibular head graft for enneking stage ii giant cell tumors of the distal radius". Microsurgery, doi 10.1002/micr, pp.1-7.

5. Draganich LF, Nicholas RW, Shusther JK, Sathy MR, Chang AF, Simon MA (1991) "The effects of resection of the proximal part of the fibula on stability of the knee and on gait". J Bone Joint Surg Am, 73A(4), 575-83.
6. Hsu RWW, Wood MB, Sim FH, Chao EYS (1997) "Free vascularised fibular grafting for reconstruction after tumour resection". The Journal of Bone and Joint Surgery, vol. 79-b, no. 1

7. Palmer AK, Dobyns JH, Linscheid RL, Elsevier (1978) "Management of post-traumatic instability of the wrist secondary to ligament rupture". The Journal of hand surgery, Volume 3, Issue 6, Pages 507-532.

8. Vander Griend RA, Funerburk CH (1993) "The treatment of giant cell tumors of the distal part of the radius". JBJS, $75 \mathrm{~A}(6)$, 899- 908.

\title{
KẾT QUẢ ĐIỀU TRI BẢO TỒN GÃY XƯƠNG TRÂ̂T KHỚP Có ĐẮP THUỐC NAM TẠI KHOA KHÁM XƯƠ'NG VÀ ĐIỀU TRI NGOẠI TRÚ, BỆNH VIỆN HN VIỆT ĐỨC
}

\section{TÓM TẮT}

Nghiên cứu được tiến hành trên 57 bệnh nhân gãy xương, trật khớp, chấn thương phần mềm, được điêu trị bảo tồn tồn tại khoa Khám xương và điêuu trị ngoại trú bệnh viện Việt Đức, trước đó bệnh nhân được điều trị ban đầu bằng đắp thuốc nam (bó lá). Mục tiêu: mô tả một số đặc điểm lâm sàng của gãy xương trật khớp có đắp thuốc nam và kết quả điều trị. Pháp nghiên cứu: Mô tả các đặc điểm lâm sàng 57 bệnh nhân gãy xương, trật khớp, chấn thương phần mềm được điều tri ban đầu bằng đắp thuốc nam, ghi nhân kết quả sau điều trị. Kết quả: Có 23/31 trường hợp gãy xương, sau bó bột ổ gãy xương vẫn còn nguyển di lệch; 3/11 trường hợp trật khớp, bán trật khớp, nắn chưa về giải phẫu; 35/57 trường hợp có viêm da tiếp xúc, $9 / 57$ trường hợp nhiễm trùng phần mềm liên quan bó lá. Đa phân người bệnh đến bó lá tại các cơ cở y tế tự phát, đông y gia truyền. Có 38/57 bệnh nhân đạt kết quả trung bình và kém sau điêuu trị. Kết luận: Xương gãy không được nắn chỉnh về giải phẫu, khồng được bất động tốt, kèm theo đó là viêm da tiếp xúc, nhiếm trùng phân mềm liên quan đến đắp lá là những yếu tố chính ảnh hưởng đến kết quả điều trị.

Tư khoá: nhiếm trùng phần mềm, gãy xương, trật khớp, thuốc nam, bó lá

\section{SUMMARY}

RESULTS OF CONSERVATIONAL TREATMENT FOR PATIENTS WITH BONE
FRACTURE AND JOINT DISLOCATION,
TREATED BY SOUTH MEDICINE AT THE

\author{
${ }^{1}$ Bệnh viện Việt Đức \\ 2Đại họ Y Hà Nội \\ Chịu trách nhiệm chính: Dương Đình Toàn \\ Email: toanduongdinh@gmail.com \\ Ngày nhận bài: 6.01.2021 \\ Ngày phản biện khoa học: 8.3.2021 \\ Ngày duyệt bài: 16.3.2021
}

Dương Đình Toàn ${ }^{1,2}$

\section{OUTPATIENT CLINIC, VIET DUC HOSPITAL}

The study was conducted on 57 patients with bone fractures, joint dislocations, softtissue injuries, conserved and treated at the outpatient clinic of Viet Duc Hospital, before that the patients were initially treated with south medicine (leaf bundles). Objectives: describe some clinical signs of dislocated fractures and joint dislocations, softtissue injuries with south medicine application and the results of treatment. Methodology: Describe the clinical features of 57 patients with bone fractures, dislocations, and software injuries that were initially treated with traditional medicine (south medicine), recording post-treatment results. Results: There were 23 out of 31 cases of fractures. 3/11 cases of dislocated joints have not yet been corrected anatomically; 35/57 cases have dermatitis, 9/57 cases of softtissue infections related to leaf bundles. 38/57 patients achieved average and poor results after treatment. Conclusion: Fractured bone is not corrected anatomically, is not inactive well, dermatitis, softtisue infections related to leaf bundles are the main factors affecting treatment results.

Keywords: softtisue infections, dermatitis, leaf bundles, south medicine

\section{I. ĐẶT VẤN ĐỀ}

Thuốc nam từ lâu được xem là môt loai dược liệu, được người dân sử dụng trong điều trị mộ số bệnh thồng thường, mang lại hiệu quả nhất định. Trong gãy xương trật khớp, thuốc nam có vai trò giảm sưng tiêu viêm, tăng cường tuần hoàn tại chỗ, có thể thúc đẩy quá trình chống viêm, liền xướng [1]. Với vai trò như trên, thuốc nam sẽ phát huy được tác dụng nếu xương gãy hay khớp trât đã được nắn về vị trí giải phẩu và được bất động tốt. Tuy nhiên hiện nay phong trào chữa bệnh bằng thuốc nam tự phát đang ngày càng nở rộ, khó kiểm soát về chất lượng thuốc cũng như 
điêu kiện hành nghề của người chữa bệnh. Nhiêuu người bệnh, bệnh tình trở nên nặng nề hơn hoặc mất đi cơ hội chữa khỏi sau khi điều trị bằng thuốc nam không đúng chất lượng, không đúng chỉ định và kỹ thuật, thậm chí phải trả giá bởi mất đi một phân chi thể. Trong thời gian gân đây, có không ít người bệnh gãy xương trật khớp đến bệnh viện Việt Đức điều trị với nhiêu biến chứng do đắp thuốc lá gây nên. Chúng tôi thực hiện đề tài này nhằm mục tiêu mô tả một số đặc điểm lâm sàng của gãy xương trật khớp có đắp thuốc nam và kết quả điêu trị.

\section{II. ĐỐI TƯỢNG VÀ PHƯƠNG PHÁP NGHIÊN CỨU}

2.1. Đối tượng nghiên cứu. Bệnh nhân được chẩn đoán gãy xương, trật khớp [2], chấn thương phân mềm đơn thuần, được điều trị ban đâu bằng bó lá, được khám và điều trị tại khoa Khám xương và điêu trị ngoại trú

2.2. Thiết kế nghiên cứu: mô tả tiến cứu

2.3. Cỡ mẫu: gồm 57 bệnh nhân

2.4. Thời gian và địa điểm nghiên cứu

Thời gian nghiên cứu: từ tháng 6/2018-6/2019.

Đia điểm nghiên cứu: Khoa Khám xương và Điều trị Ngoại trú, Viện Chấn thương Chỉnh hình, Bệnh viện Việt Đức

\subsection{Các bước tiến hành}

- Lựa chọn bênh nhân theo tiêu chuẩn lựa chọn

- Mô tả đăc điểm lâm sàng

- Can thiệp thủ thuật hoặc phẫu thuật: Điều trị kháng sinh, bó bột; Gây mê nắn bó bột; Chuyển mổ xử lý hoại tử nhiễm trùng phần mềm, viêm xương.

- Đánh giá kết quả. Các tiêu chí đánh giá (nhóm nghiên cứu tự xây dựng):

\begin{tabular}{|c|c|c|c|}
\hline & Gãy xương & Trật khớp & CT phân mềm [3] \\
\hline Tốt & $\begin{array}{l}\text { - Xương liền đúng giải phẫu } \\
\text { - Không viêm da }\end{array}$ & $\begin{array}{l}\text { - Đạt giải phâu, biên độ vận } \\
\text { động bình thường } \\
\text { - Không viêm da }\end{array}$ & $\begin{array}{l}\text { - Khỏi, không thay đổi màu sắc } \\
\text { da (không viêm da) }\end{array}$ \\
\hline $\begin{array}{c}\text { Trung } \\
\text { bình }\end{array}$ & $\begin{array}{c}\text { - Xương liền không đúng giải } \\
\text { phẫu } \\
\text { - Viêm da không nhiễm trùng }\end{array}$ & $\begin{array}{c}\text { - Đạt giải phâu, hân chế biên } \\
\text { độ vận động } \\
\text { - Viêm da khống nhiếm trùng }\end{array}$ & $\begin{array}{l}\text { - Khỏi, đế lại sẹo hoặc thay đối } \\
\text { màu sắc da } \\
\text { - Viêm da không nhiễm trùng }\end{array}$ \\
\hline Kém & $\begin{array}{l}\text { - Khớp giả, hoặc chậm liền, } \\
\text { hoặc viêm xương } \\
\text { - Viêm da nhiễm trùng }\end{array}$ & $\begin{array}{l}\text { - Không đạt giải phâu } \\
\text { - Cứng khớp } \\
\text { - Viêm da nhiếm trùng }\end{array}$ & $\begin{array}{l}\text { - Viêm da nhiêm trùng } \\
\text { - Khỏi, phải điều trị kháng sinh } \\
\text { dài ngày và/hoăc phải phấu thuật }\end{array}$ \\
\hline
\end{tabular}

\section{KẾT QUẢ NGHIÊN CỨU}

\section{1. Đăc điểm nhóm đối tượng nghiên cứu}

3.1.1. Tuổi: trung bình là $35,3(4-80)$

3.1.2. Giới:

Bảng 3.2. Đặc điểm tổn thương

\begin{tabular}{|c|c|c|c|c|c|}
\hline \multicolumn{2}{|c|}{ Gãy xương (n=31) } & \multicolumn{2}{c|}{ Trật khớp (n=11) } & \multicolumn{2}{c|}{ CT phân mềm (n=15) } \\
\hline Đâuu dưới xương quay & 9 & Trật khớp vai & 2 & Bàn chân & 3 \\
\hline Cổ xương cánh tay & 2 & Bán trật khớp cố chân & 4 & Cổ chân & 4 \\
\hline Trên lồi câuu xương cánh tay & 2 & Trật khớp quay trụ dưới & 3 & Gối & 4 \\
\hline Lồi câu ngoài xương cánh tay & 3 & Bán trật khớp gối & 2 & Bàn tay & 2 \\
\hline Xương đòn & 4 & & & Cắng chân & 2 \\
\hline Mắt cá chân & 4 & & & & \\
\hline Đốt bàn ngón chân & 5 & & & & \\
\hline Cố xương đùi & 2 & & & & \\
\hline
\end{tabular}

Nhận xét: Gặp nhiều hơn cả là gãy đầu dưới xương quay. Ngoài ra gãy lồi cầu ngoài cánh tay trẻ em có 3 trường hợ, gãy cổ xương đùi người già có 2 trường hợp

Bảng 3.3. Kêt quả sau bó lá

\begin{tabular}{|c|c|c|c|}
\hline & $\begin{array}{c}\text { Không đạạt Giải } \\
\text { phâu }\end{array}$ & $\begin{array}{l}\text { Viêm da không } \\
\text { nhiếm trùng }\end{array}$ & $\begin{array}{l}\text { Viêm da nhiếm trùng } \\
\text { (viêm tấy mô mềm) }\end{array}$ \\
\hline Gãy xương (n=31) & $23(74 \%)$ & $19(61 \%)$ & 19 \\
\hline Trật khớp $(n=11)$ & $3(27 \%)$ & $7(63 \%)$ & $2(18 \%)$ \\
\hline CT Phần mềm $(n=15)$ & & $9(60 \%)$ & $2(13 \%)$ \\
\hline Tổng & $26(62 \%)$ & $35(61 \%)$ & $9(16 \%)$ \\
\hline
\end{tabular}

Nhận xét: Với gãy xương, không đạt giải phấu chiếm tỷ lệ cao (74\%). Viêm tấy mô mềm gặp 9 trường hợp ở cả gãy xương, trật khớp và chấn thương phần mềm.
Bảng 3.1. Phân bố theo giới

\begin{tabular}{|c|c|c|c|}
\hline \multirow{2}{*}{ Giới } & Nam & 22 & $38,6 \%$ \\
\cline { 2 - 4 } & Nữ & 35 & $61,4 \%$ \\
\hline
\end{tabular}

Nhân xét: Nữ nhiêu hơn nam, chiếm $61 \%$

3.1.3. Đặc điểm tổn thương 
3.1.4. Thời gian bó lá: trung bình 13 ngày (từ 3-21 ngày)

3.1.5. Thới gian từ khi chấn thương đến khi đến khám: trung bình 25 ngày ( 7 ngày -2 tháng)

3.2. Kết quả

3.2.1. Thời gian theo dõi: trung bình 4,5 tháng (2-9 tháng)

3.2.2. Di chứng sau bó lá của nhóm gãy xương Bảng 3.4. Di chứng

\begin{tabular}{|c|c|c|c|}
\hline & Không liền Viêm xương & Can lệch \\
\hline $\begin{array}{c}\text { Gãy xương } \\
\text { (n=31) }\end{array}$ & 2 & 1 & 19 \\
\hline
\end{tabular}

Nhân xét: Can lêch là di chứng găp nhiều nhất đối với nhóm gãy xương. Một trường hợp viêm xương đường máu có liên quan đắp lá sau chấn thương phần mềm, 2 trường hợp không liên do tiêu cổ xương đùi.

\subsubsection{Kết quả điêu trị}

Bảng 3.5. Kết quả điều trị

\begin{tabular}{|c|c|c|c|}
\hline & Tốt & $\begin{array}{c}\text { Trung } \\
\text { bình }\end{array}$ & Kém \\
\hline Gãy xương $(n=31)$ & 9 & 18 & 4 \\
\hline Trật khớp $(n=11)$ & 4 & 5 & 2 \\
\hline CT Phần mềm $(n=15)$ & 6 & 7 & 2 \\
\hline
\end{tabular}

Nhận xét: Kết quả trung bình chiếm ưu thể trong cả ba nhóm

\section{BÀN LUÂN}

4.1. Đăc điểm nhóm đối tượng nghiên cứu. Tuổi trung bình là 35,3 , gặp từ trẻ em 4 tuổi cho đến người già 80 tuổi. Việc điều trị bằng đắp thuốc lá bắt nguồn từ nhân thức của người lớn. Thông tin truyền miêng thiếu kiểm chứng của người lớn về chất lượng khám chữa bệnh của các cở sở y tế tư nhân và hiệu quả điều trị bằng thuốc nam, cùng với tâm lý e ngại khi đến bênh viện công, chuyên khoa khiên người lớn hoặc tự mình tìm đến gặp các thầy lang hoặc dẫn người thân của mình đến, bao gồm trẻ em.

4.2. Đặc điểm tổn thương. Gặp nhiều nhất trong nhóm gãy xương là gãy đầu dưới xương quay ở người có tuổi. Gãy cổ xương đùi di lệch ở người già, gãy lồi ngoài xương cánh tay di lệch ở trẻ em là những tổn thương có chỉ định mổ tuyệt đối, tuy nhiên những người bệnh này cũng được các thầy lang chỉ định bảo tồn bằng bó lá. Trong quá trình hỏi bệnh, chúng tôi thấy đa phần các thây lang đều có cam kết sau bó lá là chắc chắn xương sẽ liền, mặc dù như chúng ta biết về đặc điểm tổn thương giải phẫu bệnh cũng như nguồn cấp máu cho gãy cổ xương đùi rất khó liên, đặc biệt gãy Garden 3, Garden 4. Tương tự như vậy, gãy lồi cầu ngoài xương cánh tay di lệch ở trẻ em không chỉ dừng lại ở việc liền xương mà còn phải xử lý di lệch, đặt lại diện khớp, bất động vừa đủ, tập phục hồi chức năng tích cực thì mới có thể khỏi theo đúng nghĩa. Ngoài ra các tổn thương khác mà người bệnh rất "thích" bó lá là chấn thương phần mềm cổ bàn chân, hay còn gọi là bong gân. Trật khớp và bán trật khớp cũng là những tổn thương mà người bệnh thích đến thầy lang để được "rút" khớp và bó lá.

4.3. Kểt quả sau bó lá. Theo Bảng 3.3 , có 23 bệnh nhân gãy xương (chiếm 74\%), 3 bệnh nhân trật khớp, bán trật khớp (chiếm 27\%) không đạt giải phẫu, cần phải gây mê nắn chỉnh lại. Viêm da thông thường gặp 36 trường hợp chiếm $61 \%$, đặc biệt viêm da nhiễm trùng gặp 9 bênh nhân, trong đó có 3 bệnh nhân phải mố cắt lọc (có 1 bệnh nhân vết thương hở), số bệnh nhân còn lại phải điều trị kháng sinh dài ngày. Những bệnh nhân được điêuu trị bằng bó lá hầu hết họ không được nắn chỉnh, hoặc được nắn chỉnh nhưng không đạt giải phẫu nhưng vẫn bó lá. Trong đa số các trường hợp khi bó lá bệnh nhân chỉ được bất động bằng nẹp tre, gỗ khổng đạt chuẩn, vì vậy kể cả việc nắn chỉnh ban đầu là đat thì phương pháp bất động không tốt cũng dễ dàng gây di lệch thứ phát. Sự tiếp xúc trực tiếp với thuốc lá gây nên tình trạng viêm da là hiện tượng gặp khá phổ biến. Khi tổ chức phần mềm đang giai đoạn sưng nề, tụ máu là điều kiện thuận lợi cho vi khuẩn thâm nhập trực tiếp qua da gây tình trạng nhiễm trùng, hay gặp là nhiễm trùng mô mềm [4]. Đặc biệt nếu trên da có vết thương hở thì nhiểm trùng là điều tất yếu nếu đắp lá trực tiếp vào vết thương (đây là chống chỉ đinh của đắp thuốc lá).

4.4. Kết quả điêu trị . Với thời gian bó lá trung bình 13 ngày (từ 3-21 ngày), thời gian từ khi chấn thương, bó lá cho đến khi đến khám trung bình trung bình 25 ngày (7ngày - 2 tháng). Trong đó đa số các trường hợp phải gây mê nắn lại (Bảng 3.3). Những trường hợp thời gian bó lá kéo dài thường kèm với đên khám muộn, do vậy tình trạng can lệch, cứng khớp, viêm tấy phần mềm gặp phổ biến. Những trường hợp viêm tấy phần mềm sau bó lá, phải điều trị kháng sinh dài ngày nên việc nắn chỉnh vô cùng khó khan, kể cả phẫu thuật. Tương tự, việc nắn chỉnh xương đến muộn cũng gặp nhiều khó khăn, đa số không mang lại kết quả như mong muốn. Chính vì vậy, kết quả 22/31 trường hợp gãy xương, 7/11 trường hợp trật khớp, bán trật khớp và $9 / 15$ trường hợp chấn thương phần mềm có kết quả kém và trung bình (Bảng 3.5) sau điều trị trung bình 4,5 tháng.

\section{KẾT LUÂNN}

Qua tiếp nhận, điều trị, theo dõi, đánh giá kết 
quả điều tri cho 57 bệnh nhân, gồm những trường hợp gãy xương, trật khớp, chấn thương phần mềm, được bó lá trước đó, chúng tôi rút ra những kết luận sau:

- Có 23/31 trường hợp gãy xương, sau bó bột ổ gãy xương vẫn còn nguyên di lệch, trong đó hay gặp nhất là gãy đầu dưới xương quay

- Có 3/11 trường hợp trật khớp, bán trật khớp, khớp nắn chưa đạt giải phẫu

- Có 35/57 trường hợp có viêm da tiếp xúc sau bó lá

- Có 9/57 trường hợp nhiễm trùng phần mềm liên quan bó lá

- Đa phần người bệnh đến bó lá tại các cơ cở y tế tự phát, đông y gia truyền
- Có 38/57 bệnh nhân đạt kết quả trung bình và kém.

Xương gãy không được nắn chỉnh về giải phẫu, không được bất động tốt, kèm theo đó là viêm da tiếp xúc, nhiễm trùng phần mềm liên quan đến đắp lá là những yếu tố chính ảnh hưởng đến kết quả điều trị.

TÀI LIỆU THAM KHẢO

1. Nguyễn Nhược Kim (2006). Bệnh học ngoại khoa-Y học cố truyên. NXB Y học

2. Nguyễn Đức Phúc (2010). Bệnh học ngoại khoa. NXB Y hoc

3. Pediatr Ann (1997). General principles in treating soft tisue injurry. Jan, 26(1): 2015.

4. Phạm Văn Trịnh (2007). Bệnh học Ngoại-Phụ Y học cổ truyền. NXB Y học

\section{NHẬN XÉT MộT Số ĐĂC ĐIỂM VỀ PHÍA ME VÀ THAI NHI Ở SẢN PHỤ Có THAI NGÔI MỐNG SINH TẠI BỆNH VIỆN PHỤ SẢN THÁI BİNH TRONG HAI NĂM 2007 VÀ 2017}

\section{TÓM TẮT}

Mục tiêu: So sánh các một số đặc điểm về phía me và thai nhi ở sản phụ có thai ngôi mông từ 28 tuẩn trong hai năm 2007 và 2017. Đối tượng và phương pháp nghiên cứu: nghiên cứu hồi cứu trên 443 sản phụ có thai ngôi mông từ 28 tuần sinh tại Bệnh viện Phụ sản Thái Bình. Kết quả: Tỷ lệ ngồi mông nẳm 2007 là 2,35\%, năm 2017 là 2,0\%. Tỷ lệ ngôi mông hoàn toàn năm 2007 là $88,7 \%$, năm 2017 là 90,6\%. Tuổi trung bình của sản phụ năm 2017 cao hơn so với năm 2007 (năm 2017: 31,7 \pm 5,9 tuổi, năm 2007: 29,8 $\pm 5,5$ tuổi; $p<0,05$ ). Tiền sử sản khoa: tỷ lệ sản phụ đẻ con so năm 2007 là 52,4\%, năm 2017 là $50,9 \%$; tỷ lệ sản phụ đẻ con rạ mổ lấy thai năm 2007 là 82,6\%, năm 2017 là 93,3\%. Tỷ lệ ngôi mông võ̃ ối khi chuyển dạ năm 2007 (14,3\%) thấp hơn có ý ngĩa thống kê so với năm 2017 (24,7\%) $(p<0,05)$. Tuối thai nhi khi sinh ra cả hai năm đa số đều từ 38 - 41 tuần (năm 2007 là 83,3\%, năm 2017 là $82,2 \%)$, tỷ lệ ngôi mông non tháng 28 - 33 tuần năm 2007 là 4,2\%, năm 2017 là 1,8\%. Trọng lượng thai nhi khi sinh ra cả hai năm đa số đều tử $3000 \mathrm{~g}$ trở lên (2007 là 54,7\%, năm 2017 là 57,8\%). Không có sự khác biệt có ý nghĩa thống kê về tỷ lệ ngôi mông, tiền sử sản khoa, phân loại ngôi mông, tuổi thai nhi và trọng lượng thai nhi ở cả 2 năm.

\footnotetext{
${ }^{1}$ Trường Đại học Y Dược Thái Bình

${ }^{2}$ Bênh viên Phu Sản Thái Bình

Chịu trách nhiệm chính: Bùi Minh Tiến

Email: Tienbm@tbmc.edu.vn

Ngày nhận bài: 5.01 .2021

Ngày phản biện khoa học: 9.3.2021

Ngày duyệt bài: 17.3.2021
}

\section{Bùi Minh Tiến', Trần Xuân Hiệp ${ }^{2}$}

Tư khóa; tỷ lệ và phân loại ngôi mông, tiền sử sản khoa, tuổi thai, trọng lượng thai nhi.

\section{SUMMARY}

ASSESSING SOME OF CHARACSTERISTICS ON MOTHER AND FETUS IN BREECH PREGNANT WOMEN BORN IN THAI BINH OB\&GY HOSPITAL IN TWO YEAS 2007 AND 2017

Objective: To compare of some of characteristics on the mother and fetus in the breech pregnant women from 28 weeks in two years 2007 and 2017. Methods: research was designed as a retrospective study on 443 in breech pregnant women from 28 weeks of birth in Thai Binh OB \& GY Hospital. Results: The study results showed: The breech presentation rate in 2007 was $2.35 \%$, in 2017, 2.0\%. The full- breech presentation 2007 rate was $88.7 \%$, in $2017,90.6 \%$. The median age of the maternity year 2017 was higher than in 2007 (2017:31.7 \pm 5.9 , year 2007:29.8 \pm 5.5 yrs; $p<0.05)$. Obstetric history: The rate of childbirth in the year 2007 is $52.4 \%$ in 2017, $50.9 \%$; The prevalence of Cesarean section in multipara in 2007 was $82.6 \%$, in $2017,93.3 \%$. The incidence of breech presentation wich has amniotic broken in labor in $2007(14.3 \%)$ lower mean statistically compared to the year 2017 (24.7\%) (P < $0.05)$. The gestational age of birth both years from 38 to 41 weeks (in $2007,83.3 \%$, in 2017 is $82.2 \%$ ), the rate of breech presentation has preterm birth 28-33 Weeks in 2007 is $4.2 \%$, in 2017 is $1.8 \%$. The birth weight of both years was born between $3000 \mathrm{~g}$ and above (2007 54.7\%, 2017, 57.8\%). There are no statistically significant differences in the rate of breech presentation, obstetric history, breech presentation classification, fetal age and fetal weight in both 2 years. 